\title{
Sustainable livelihoods approaches for exploring smallholder agricultural programs targeted at women: Examples from South Africa
}

\author{
Stefanie Lemke ${ }^{a}$, Farideh Yousefia ${ }^{a}$ Ana C. Eisermann ${ }^{a}$, Anne C. Bellows ${ }^{a}$, University of Hohenheim
}

Submitted 16 March 2012 / Revised 29 May 2012 / Accepted 18 June 2012 / Published online 17 August 2012

Citation: Lemke, S., Yousefi, F., Eisermann, A. C., \& Bellows, A. C. (2012). Sustainable livelihoods approaches for exploring smallholder agricultural programs targeted at women: Examples from South Africa. Journal of Agriculture, Food Systems, and Community Development, 3(1), 25-41. http://dx.doi.org/10.5304/jafscd.2012.031.001

Copyright (C) 2012 by New Leaf Associates, Inc.

\begin{abstract}
Smallholder farming can play a crucial role in contributing to food supplies and autonomy at the household and community level in rural areas, yet this has been challenging to evaluate. In South Africa, smallholder agriculture faces multiple challenges due to historical injustices regarding access to land and resources and to post-apartheid policies that failed to promote rural development. Drawing on the Sustainable Livelihoods Framework and employing a mixed methods approach, we explore through participant observation and interviews the prospects of

a University of Hohenheim; Department of Gender and Nutrition, Institute for Social Sciences in Agriculture (430b); 70593 Stuttgart, Germany.

Farideh Yousefi: f.yousefi@uni-hohenheim.de

Ana C. Eisermann: anna eisermann@yahoo.com.br

Anne C. Bellows: anne.bellows@uni-hohenheim.de

* Corresponding author: Stefanie Lemke; +49 711459 22655;

stefanie.lemke@uni-hohenheim.de
\end{abstract}

smallholder agricultural programs for establishing sustainable livelihoods, facilitated by civil society organizations and targeted at rural black and colored South African women. Participation in these programs enabled women access to various livelihoods assets: education and capacity-building (human assets); land (natural assets); tools and infrastructure (physical assets); stipends and income from selling their produce (financial assets); and networking (social assets). Operational challenges included divergent expectations on the side of project facilitators and participants; lack of communication; participant dependency on the organizations; lack of access to markets; and programs' lack of financial sustainability. Our findings suggest that, while these programs are not yet sustainable, they stimulate an awareness of possibilities, visions, ownership, and rights that can have a long-term effect on the livelihoods of these women. In evaluating program success, especially in the initiation phases, it must be remembered that structural barriers to the improvement of rural women's livelihoods are formidable, and few South 
African models or alternatives are presently available to help civil society organizations formulate new opportunities.

\section{Keywords}

civil society organizations, land reform, mixed methods approach, smallholder agricultural programs, South Africa, sustainable livelihoods framework, women

\section{Introduction}

In many parts of the world, rural livelihoods are closely linked to agriculture, often performed at a smallholder and subsistence level. Nevertheless, rural food producers are ironically and tragically the most food-insecure demographic group (Windfuhr \& Jonsén, 2005). In light of the global food crises and the fact that many people cannot afford adequate food, the present Special Rapporteur on the Right to Food, Olivier de Schutter, has pressed for attention to the rights and voices of small farmers and to agro-ecological approaches employed particularly by them to achieve food security (De Schutter, 2011). As Lahiff (2008a) states and many others underscore, the dramatic rise in food prices serves as a crude reminder of global dependencies on dominant agribusinesses for staple food needs, demonstrating that an alternative vision of diverse agricultural production and more resilient, less costly, and more environmentally sustainable options needs to be developed (Cousins, 2007; Grethe, Dembélé, \& Duman, 2011; International Assessment of Agricultural Knowledge, Science and Technology for Development [IAASTD], 2009; Windfuhr \& Jonsén, 2005).

The missions to promote smallholder agriculture and develop local food systems, however, face multiple challenges. Rural peoples and food producers across the urban-rural expanse, and women as a particularly marginalized group, are often disconnected and alienated from the land, tools, skills, and knowledge systems that might develop prosperous local food systems and sustainable livelihoods. In many cases, land tenure and rights are insecure and land costs consistently rise, resulting in rural people being displaced by powerful interest groups, including through the recent phenomenon known as "land-grabbing" (FoodFirst Information and Action Network [FIAN] International, 2010, p. 8). In other cases, the goal of land access, in fact, is not particularly or exclusively for agricultural production.

In South Africa, adding to the challenges described above, the history of colonialism and apartheid created racial and political inequities and dispossession, especially of land. South Africa is not immediately associated with hunger and food insecurity, as it represents one of the most stable and wealthy economies in Africa and recently attained the status of newly industrialized country. However, despite South Africa being food secure at the national level, large sections of the predominantly black and colored ${ }^{1}$ population face poverty, inequality, high unemployment, and food insecurity (Von Grebmer, Torero, Olofinbiyi, Fritschel, Wiesmann, Yohannes, Schofield, \& Von Oppeln, 2011; World Bank, 2011). About half of these households are estimated to be food insecure and one out of five children aged 1-9 years is stunted, with children living on farms displaying even higher stunting rates than the national average (Labadarios, Swart, Maunder, Kruger, Gericke, Kuzwayo... \& Dannhauser, 2008). Strategies that could make a contribution to increased food supplies are urgently required, with small-scale food production having been associated with enhanced food and nutrition security at the household level (Aliber \& Hart, 2009; Faber, Witten, \& Drimie, 2011).

In this paper we explore whether agricultural programs targeted at rural black and colored women, orchestrated by two civil society organizations (CSOs) in different parts of the

\footnotetext{
1 The apartheid laws intended for "racial classification" designed a social hierarchy, attempting the imposition of "race groups," mainly White, Colored, Black and Indian, on individuals in a single, complex system. Because this categorization has some basis in reality and also in apartheid history, no discussion is fruitful without first referring to these categories and their respective backgrounds. Initially, reference will therefore be made to black women (mostly Xhosaspeaking) and colored women (of a more "mixed" origin, and mostly Afrikaans-speaking), all involved in the agricultural programs described here. For reasons of simplicity we later refer to "women" or "participants."
} 
Western Cape, South Africa ${ }^{2}$ can contribute to sustainable livelihoods, and whether the promotion of smallholder farming and local food systems is attractive to marginalized peoples whose relationship to farming and land has been manipulated since the colonial era. Drawing on the Sustainable Livelihoods Approach (SLA) and employing mainly in-depth qualitative methods, we investigate underlying structural conditions of livelihoods at the household and community level, focusing on individuals' and groups' capacities and access to various livelihood assets.

\section{Background}

South Africa: Loss of Rural Livelihoods and Challenges of Land Reform

In South Africa, land must be understood in its historical context, which was marked by three main processes: colonial expansion beginning in 1652, the discovery of minerals and subsequent industrialization at the end of the nineteenth century, and the policies of apartheid in the twentieth century (Kepe, Hall, \& Cousins, 2008, p. 145). Virtual enslavement first of the indigenous Khoisan inhabitants into the colonial economy and later of the black and colored population into the mining industry and farming enterprises denied them dignity and self-determination. The loss of access to land, especially as initiated by the Natives Land Act of 1913, destroyed land-based livelihoods and the remnants of the agricultural subsistence economy of the majority of the South African population (Van Onselen, 1996). This further resulted in farm workers and their families being trapped on commercial farms, lacking rights and legal redress and further lacking the skills to be involved in the wider economy, facing ongoing poverty as well as income and residential insecurity (Atkinson, 2007). Agriculture increasingly became a task for employment and income, not the centuries-old

\footnotetext{
2 This research is part of a larger project on food security and the right to adequate food in the context of land and agrarian reform in South Africa (Lemke, 2010). Two masters' thesis projects carried out by Farideh Yousefi and Ana Eisermann in 2010 that were supervised by Stefanie Lemke and Anne Bellows contribute to this paper.
}

engagement with the local environment to maintain household nutritional health, community security, and identity. Nevertheless, it is estimated that 2.5 million households are engaged in some crop production, with most households procuring additional food supplies for their own consumption (Altman, Hart, \& Jacobs, 2009). These households also depend on formal and informal employment, remittances from migrant household members, welfare transfers, and microenterprises, as is the case in many other parts of Southern Africa (Shackleton, Shackleton, \& Cousins, 2000). In the particular example of South Africa, multiple livelihoods developed partly as a response to dispossession, overcrowding, and landlessness in the so-called former homelands (Cousins, 2007) and are often more a response to crisis than a coping strategy for stability (Loevinsohn \& Gillespie, 2003). The capacity of rural households to contribute to local economic development is questioned, as they have often moved away from agricultural production and employ various other livelihood strategies (Bank, 2005).

South African land-reform policy seeks to redress loss of access to land and thereby social inequalities. Land reform entails three parts:

- Restitution, which seeks to return land or cash payment to people dispossessed after 1913;

- Redistribution, which provides government grants (settlement and land acquisition grants) to help people who do not fall under the restitution regulations to acquire land; and

- Tenure reform, which aims to bring all people occupying land under a unitary, legally validated system of landholding, to provide for secure forms of land tenure, help resolve tenure disputes, and make awards to provide people with secure tenure (Department of Land Affairs, 1997).

According to the latest Status Report on Land and Agricultural Policy in South Africa, 2010, by 2009, only 1.4 million acres (5.67 million hectares) or $6.9 \%$ of 
agricultural land had been transferred (Greenberg, 2010, p.4); the overall target to transfer 30 percent of agricultural land by 2014 was shifted to 2025 . Land reform has been criticized for a number of issues, such as poor support for emerging new farm owners after transfer settlements have been finalized; lack of government coordination between different spheres (e.g., entitlements, education, agricultural policies, and land reform) and scales (e.g., national and local); and failure to integrate land reform within broader rural development, limiting its potential to promote social equity and revive rural economies (Lahiff, 2008b). While recent efforts to revise land reform and agricultural policies place a renewed focus on a smallholder strategy, according to Greenberg (2010, pp. 41-42), the challenge of building a more racially inclusive and equitable agricultural model has to confront the existing economic power of commercial agriculture and agro-industry with the aim of transforming it. This requires various strategies, such as de-concentration, decentralization of valueadding activities, and the stimulation of local markets, based on the initiative and activities of the producers themselves. Part of this effort must include addressing rural women's and men's dignity, land tenure, personal security, and human rights overall.

Women, Smallholder Farming, and Livelihoods Although women have been called the key to household food security (Food and Agriculture Organization of the United Nations [FAO], 2011; International Food Policy Research Institute ([IFPRI], 2005; Kent, 2002; Quisumbing, Haddad \& Pena, 1995; Quisumbing \& Smith, 2007), gender is not yet adequately addressed and integrated into discussions on how to achieve adequate food supplies. Female farmers in all regions have less access to land and livestock and less access to agricultural inputs, credit, education, extension, and other services than do men, due to social norms (FAO, 2011). Further, paid farm labor for women is often limited to part-time and seasonal work, and their wages are characteristically lower than those of men (FAO 2011; cf. World Bank, FAO, International Fund for Agriculture Development [IFAD], 2009). According to the FAO (2011), women in sub-Saharan Africa have the highest average agricultural labor-force participation rates in the world, exceeding 60 percent. ${ }^{3}$ In South Africa women represent 61 percent of people involved in farming, and they produce more food for household consumption than men do (Altman et al., 2009). Despite their crucial role in providing household food security, and despite the comprehensive inclusion of women's rights in the South African constitution, women face severe discrimination, with perpetuating social structures such as patriarchy and paternalism reinforcing their disempowered position within the household and community (Reddy \& Moletsane, 2009). In the context of large-scale commercial agriculture, employment and housing contracts on farms are mostly linked to men. This results in:

- women having no formal housing contract and depending on their male partner for accommodations;

- impacting resource allocation within the household, which contributes to women's limited decision-making power; and

- dependency on male partners and livelihood insecurity for female farm workers should the men leave the farm or stop working (Lemke, Bellows, \& Heumann, 2009).

The FAO's The State of Food and Agriculture 2010-11 reiterates the call for policy interventions that close the gender gap in agriculture and rural labor markets by: (1) eliminating discrimination against women with regard to access to resources; (2) creating enabling infrastructure and technologies to provide women with more time for productive activities; and (3) facilitating women's participation in flexible, efficient, and fair rural labor markets (FAO, 2011, pp. 5-6). To this end, we recommend the Sustainable Livelihoods Approach as an analysis. It can serve not only to

\footnotetext{
${ }^{3}$ The agricultural labor force includes people who are working or looking for work in formal or informal jobs and in paid or unpaid employment in agriculture. This includes self-employed women as well as women working on family farms (FAO, 2011, p. 7).
} 
(re-)identify known aspects of discrimination, but also to uncover women's livelihood assets that policy efforts might augment to leverage transformation of individuals and groups through and beyond the context of their vulnerabilities.

\section{Methodology}

\section{Sustainable Livelihoods Approach}

The Sustainable Livelihoods Framework, as developed by the Department for International Development (DFID, 1999), serves as theoretical framework and analytical structure to explore the agricultural programs observed here and their impact on livelihood options of participating women. Drawing on the earlier definition of Sustainable Livelihoods by Chambers \& Conway (1992) and as developed further by Scoones (1998, p. 5), a livelihood "comprises the capabilities, assets (including both material and social resources) and activities required for a means of living. A livelihood is sustainable when it can cope with and recover from stresses and shocks, maintains or enhances its capabilities and assets, while not undermining the natural resource base." At the household and community level, livelihood assets (a combination of physical, natural, financial, social, and human capital) play an essential role for households and individuals in pursuing strategies (livelihood strategies) with the aim of achieving desired goals (livelihood outcomes). Livelihood outcomes in turn impact livelihood assets. National- and provincial-scale institutional and policy structures and processes influence the capability to amass and orchestrate livelihood assets and livelihood strategies, directly shaping the vulnerability context of individuals and groups. Engaging a sustainable livelihoods research approach therefore requires investigating the conditions of access to a full range of resources for insecure populations.

"Sustainable Livelihoods Approaches" (SLA) became increasingly central to international debates about development, poverty reduction, and environmental management in the 1990s. SLA have been criticized for not adequately reflecting power relations, although the initial approach presumed that an understanding of social relationships, their institutions and organizations and their embedded power dynamics is crucial to designing interventions that improve sustainable livelihood outcomes (Scoones, 1998). In line with Scoones (2009) we argue that SLA research continues to offer a valuable and holistic approach for an integrated analysis of complex and highly dynamic research contexts. SLA research is able to bridge academic and policy divides, particularly between the natural and social sciences, and to challenge single-sector development approaches; it emphasizes the importance of local knowledge and the inclusion of participatory research methods as a means to help to understand complex local realities and to facilitate engagement and learning between local people and outsiders. The limitations of SLA can benefit from using complementary tools and frameworks. ${ }^{4}$

\section{Data Collection}

Mixed methods were applied with an emphasis on qualitative approaches, but also included quantitative socio-demographic and socio-economic household data. Initial introductory visits to the respective programs and communities in case studies reported here were facilitated through host organizations and served to inform research participants about the aims of research and to request permission to pursue the study. Participant observation was applied with researchers actively engaging in the daily activities of the people studied, enhancing acceptance of researchers and establishing relationships of trust. This further provides in-depth insights into social dynamics, e.g., decision-making processes and power

\footnotetext{
${ }^{4}$ SLA has for example been integrated with agroecology, with both approaches sharing core concepts but also diverging with regard to certain aspects (Amekawa, 2011). In another study, SLA was applied in combination with the socio-ecological framework that places specific emphasis on the vulnerability context and explains human development and adaptation in the context of the coupled human-environment interactions (Motsholapheko, Kgathi, \& Vanderpost, 2011). To address the challenge of discontinuity of scale between different frameworks, Rao \& Rogers (2006) suggest aggregating indicators derived at the lowest level of spatial hierarchy, as is the case for SLA with a focus on the household and community level, to larger scales such as agroecosystems and other regional scales using spatial analysis tools like GIS.
} 
relations. All events observed were recorded in a field book. In addition, personal feelings were recorded and reflected upon, so as to reveal possible bias. Interviews were carried out at a later stage of research after the first phase of observation and participation. This enabled us to adapt interview questions to the respective contexts. Interviews were conducted in English ${ }^{5}$ and were composed mainly of open-ended questions. Interviews were divided into two phases. The first phase was carried out with participating women at the program sites, addressing perceptions regarding the respective programs and how these affected various livelihood assets and livelihood outcomes. This was followed by a second interview phase that took place mainly within the communities and households of these women, once they felt comfortable about accepting visitors in their homes. Questions in interviews covered issues such as household composition, intrahousehold dynamics, household food situation and resource allocation, social networks, and perceptions of relatives regarding the participation of the women in the project. In addition, information was obtained through semistructured interviews with the directors, project managers or coordinators, and other personnel of both organizations, exploring their aims and perceptions regarding project implementation.

\section{Data Analysis}

Notes from the field books were coded to establish emerging themes and categories. As the sample size was small, the coding process was done by hand, instead of using software for qualitative data analysis. Emerging categories were analyzed and interpreted. Answers to open-ended questions were coded following the same steps. Using a variety of research strategies provided comprehensive analysis (Creswell, 2009; Denzin \& Lincoln, 2008). For continuous reflection and review, regular supervision meetings in the form of academic colloquia and international workshops were held with academic peers and experts.

\footnotetext{
${ }^{5}$ All research participants felt comfortable with English, which was either their second or third language.
}

\section{Agricultural Programs Facilitated by CSOs Toward Realizing Sustainable Livelihoods}

The case studies presented here are situated in the Western Cape province of South Africa, known for its deciduous fruit and viticulture. The province has the largest share of agriculture of all provinces and the highest number of farm workers (Statistics South Africa [Stats SA], 2009). Research was carried out in collaboration with two local CSOs that offer agricultural programs specifically targeting women. The purpose here is not to evaluate these programs as such, but rather to explore them as alternative approaches for engaging in smallholder agriculture and to consider whether such programs are able to support and realize livelihood options for marginalized groups in South Africa.

\section{Case Study: Agricultural and Life Skills Training Facilitated by the Grootbos Foundation}

\section{Beginnings of the Growing the Future Program}

The Grootbos Foundation is a nonprofit organization set within the Grootbos Private Nature Reserve, located in Gansbaai, southeast of Cape Town, in the Western Cape province of South Africa. The foundation was established in 2004 and states as its mission: "The conservation of biodiversity of Grootbos and its surrounds and development of sustainable nature based livelihoods through ecotourism, research, management and education" (Grootbos Foundation, 2010). The owners of the nature reserve established the fivestar Grootbos eco-lodge in the 1990s. The Grootbos Foundation is financially supported through funds from this tourism business, donations, and income generated from its diverse programs. The "Growing The Future" (GTF) agricultural and life skills training program that was established in 2009 targets unemployed rural women from two neighboring townships. The economic recession in 2008 had led to loss of employment for large numbers of people in the area, most of whom had migrated to the Western Cape from the provinces of Gauteng and Eastern Cape in search of work (Bhaktawar \& Burger, 2009). Each year eight unemployed women receive training on organic vegetable and fruit production, 
animal husbandry, and bee keeping, as well as education on literacy, numeracy, basic computer skills, health and safety issues, HIV/AIDS awareness, and business planning. The program's produce is sold to the two restaurants at the Grootbos lodge, surrounding restaurants in the area, and a local market. With graduation, the women receive a certificate $^{6}$ that, according to the Grootbos Foundation, will enable them to find employment in various sectors, pursue their education, or establish their own business, either by growing vegetables in the township, contributing to household food supplies, or alternatively, by engaging in commercial food production through co-operative land use in their home areas (Privett \& Lutzeyer, 2010).

During the time of this research, six of eight women in the first project year graduated. They ranged in age from 25 to 33. Except for one woman who grew up in this area, the other women had migrated from the Eastern Cape to the Western Cape during the past five to 13 years. None of the women had finished secondary school. They stated that they would have liked to continue their education, but had to work to contribute to their family's livelihood. The households of these women were composed of three members on average, with a range of one to seven members. The women lived in a township at a distance of approximately 9.3 miles (15 kilometers) from the project site, where they rented either small brick houses or corrugated iron shacks composed of only one or two rooms and devoid of sanitation facilities. The township has a health clinic and grocery stores and is adjacent to a major road. As public transport is lacking, people have to make use of expensive private minibus taxis.

\section{Challenges and Sustainability of the Program}

This research was carried out during the second half of this program's first year of inception.

\footnotetext{
${ }^{6}$ This certificate was designed based on the "Adult Basic Education and Training" (ABET) curriculum, a nationally recognized certificate that was established by the South African Department of Education (ABET, 2011). The Grootbos Foundation had tried to register as an ABET training center, but was not successful.
}

Naturally, each new program undergoes a start-up phase and adaptations are necessary before it develops into a more sustainable operation. The results presented here should be seen therefore in light of the early stage of this program. Several challenges were experienced during the initial design of the program related to available resources. As the plot of land designated for the program consisted of sandy soil with very poor nutrient content that was not suited for growing vegetables, huge amounts of compost had to be added. This required a large amount of physical labor, time, and financial capital input in the beginning, resulting in lower returns than expected. Further, funds to employ project managing and training staff were limited. This resulted in the manager of the program being responsible for establishing the farming operation and, simultaneously, a teaching program for practical and theoretical agricultural skills, being assisted by one part-time teacher. Especially in the start-up phase this posed considerable challenges and might have led to limitations in the ability to address the specific needs of the participating women. Participatory research revealed that different perceptions existed regarding the aims of the program. While the Grootbos Foundation regarded it as a first step toward establishing smallholder agricultural enterprises in the future, most of the women had joined the program because they were unemployed and had no other prospects for finding work. Interviews with family members of the women's households revealed that there was little knowledge about the contents of the GTF program, and that it was considered a work place rather than a training program. These diverging perceptions resulted in tensions between the GTF management and the participants. There was a lack of agreement regarding, for example, the amount of the stipend that the women received from the Grootbos Foundation; the performance of certain daily tasks that were regarded by the women as agricultural "labor" and not as "training"; and ownership of the program. ${ }^{7}$ Regarding the aim of the GTF pro-

\footnotetext{
${ }^{7}$ In line with our participatory approach, following requests of the participants, Farideh Yousefi offered a training module on healthy nutrition and food processing. Further, as a result of
} 
gram to become financially viable and sustainable, it recovered only 60 percent of its costs in 2010 . Among the challenges were the limited size of the farming operation, comprising about half an acre $\left(2000 \mathrm{~m}^{2}\right)$ that does not allow for producing sufficient quantities, and limited access to markets in this area for specialized organic products.

\section{Impact of the Program on the Livelihoods} of Participating $W$ omen

The women received a weekly stipend of 220.00 ZAR from the GTF program, amounting to roughly $900.00 \mathrm{ZAR} /$ month (USD131.38), ${ }^{8}$ constituting less than half the average salary $(2,000.00$ $\mathrm{ZAR} /$ month) in the tourism sector where most of the women were previously employed. This weekly stipend contributed to household incomes, but was not sufficient to cover all needs, a concern the women raised frequently, as most of them were the main income earners for their households and had to provide food to their family. Notably, the women had no prior agricultural experience, except for one woman who had worked at a farm previously. The women appreciated the fact that they were given their own small garden plot at the program site, where they planted vegetables, varying according to season. This produce mainly was for their own consumption, but was also sold to neighbors in the township. In summer, the women bought vegetables at a price cheaper than market value from the GTF program and sold them with some profit in the township. This extra income contributed to their ability to buy other foodstuffs, such as rice and meat. However, the possibility of gaining an additional income through the sale of certain products, such as organic eggs and honey, is limited, as people living in the township cannot afford these comparatively expensive products.

As our findings show, the GTF program contributed to enhancing certain livelihood assets

this research a farm stall was established in close proximity to the eco-lodge, and regular meetings between management and other staff of the various programs of the foundation were initiated.

${ }^{8}$ USD1.00 was equal to 6.85750 ZAR (South African Rand) at the time of this research. http://www.xe.com/ucc/convert. cgi? Amount $=1 \&$ From $=U S D \& T_{0}=$ ZAR\&image $. x=40 \&$ image. $=13$ of the participating women, providing income from the weekly stipend, even though small, as well as some additional income from selling surplus produce from the project (financial assets); and agricultural knowledge and various other training, e.g, food processing, basic computer skills, and business planning (human assets). Further, the women established social networks among each other (social assets) through this program. For those women who want to pursue farming activities after finishing the program, the Grootbos Foundation assists in the start-up phase by providing tools and seeds (physical assets), and by facilitating access to communal land (natural assets) in the neighboring township, where the women have the option of engaging in an agricultural cooperative, assisted by GTF staff. These combined livelihood assets have a positive effect on the vulnerability context and on the livelihood outcomes of these women. The women unanimously stated that the practical and theoretical skills that they acquired during the program equipped them with better chances to find employment.

Despite these perceived benefits, the chances of establishing sustainable livelihoods in the agricultural sector are very limited, for several reasons. Due to the lack of employment prospects when the program ended, the Grootbos Foundation extended the duration of the program for the first group of women by six months so as to enable a transition phase. One woman was recruited into the GTF program as an assistant trainer. None of the other women pursued agricultural activities, as this was not a livelihood option for them. Among the constraints they experienced were limited access to natural assets such as land and lack of access to financial assets and support structures in the Eastern Cape. Even if the women could start their own small-scale farming operation, this can provide neither sufficient food nor income for them and their families to sustain their lives, and can therefore only complement other livelihood options. Such alternative options, however, do not exist in the Eastern Cape, which is exactly why they migrated to the Western Cape in the first place. The possibility of staying where they currently live and to engage in agriculture for producing food for own consumption and/or selling the surplus 
requires a considerable amount of time, which is needed instead for engaging in employment that can generate an adequate income.

\section{Case Study: Agricultural Cooperatives Facilitated by Women on Farms Project}

\section{Beginnings of the Cooperative Program}

The Women on Farms Project (WFP) is a South African nongovernmental organization (NGO) founded in 1996 and located in Stellenbosch in the Western Cape province, northeast of Cape Town. The main aim of WFP is to help lead to a society that treats women who live and work on farms with dignity and respect in accordance with the constitutional rights guaranteed to all South African citizens (Women on Farms Project, 2009a). WFP works toward strengthening capacity through education and training, research, lobbying, campaigning, and organization-building. In support of these aims, the organization engages programs in health and empowerment, labor rights, land and housing, social security, agricultural cooperatives, and a program tailored specifically to young women (Women on Farms Project, 2009b). The WFP's cooperatives program, which forms the focus of this case study, assists in the formation of rural entrepreneurial cooperatives exclusively for women on remote and isolated farms, who are either unemployed or temporarily employed. Once women decide to form a cooperative, WFP offers assistance in gaining access to land and applying for funds. WFP further offers workshops on cooperative governance, training in various farming activities, business planning, and marketing. Women who are part of the cooperative program are invited to engage in the activities of other programs offered by WFP as well. During the period of field observation from June to October 2010, WFP assisted two cooperatives that had been established in 2006 and 2008. Only one of these cooperatives had, however, started its production activities by 2010 and therefore lends itself to the case study illustrated here.

The idea for the Ceres Cooperative was born in 2008, when four of the current members approached WFP. The women had learned about the cooperative program while participating in other programs offered by WFP. However, it was not until June 2010 that the Ceres Cooperative finally accessed land on the scale of 2.5 acres $(1$ hectare $)$ and a four-room house that can be used for production and for storage of farming implements and materials. The land and the house are provided by a church located outside the farm where the women live, and one hour's walking distance. It is important to note that no formal contract existed for the lease of this plot of land at the time of the research. An agreement was signed, with WFP ensuring the cooperative mentoring for an 18-month start-up period; cooperative members committed to work toward the development of this cooperative. The women decided to grow Grey Oyster mushrooms (Pleurotus ostreatus), although they had neither consumption nor production experience with mushrooms. This decision was based in part on the fact that the other cooperative had earlier decided on producing mushrooms and that this was perceived as a profitable venture.

At the time of this research the Ceres Cooperative was composed of six women, who were 20 to 64 years of age. Five of the cooperative members were unemployed while one woman worked as a seasonal farm worker. None of the women had finished secondary school. Average size of the cooperative members' households was eight, with a minimum of two and a maximum of 11 members. All the women lived on the premises of a white farm owner, with none of them having a housing contract, meaning that they were dependent on male family members for shelter. The houses were made of bricks, usually consisting of two or three rooms, supplied with running water and electricity. Some had sanitation facilities inside the house, or, in other cases, outside pit latrines. There were no public services, such as transportation and health services, or grocery stores in close proximity of the farm, adding to the highvulnerability context of people living and working on farms. Once per month the cooperative members go to the nearest town at a distance of about 31 miles (50 kilometers) to buy food, clothes, and others necessities, having to make use of expensive private minibus taxis. 
Challenges and Sustainability of the Program

The Ceres Cooperative experienced difficulties when preparation for mushroom cultivation started in July 2010. During this time one of the authors stayed at the house of a cooperative member over a period of three weeks. ${ }^{9}$ The women expected technical assistance from WFP during this start-up period and felt that a two-day training workshop on mushroom production provided them with insufficient knowledge, having been conducted in an environment different from the conditions they faced. It was further observed that communication between the cooperative management team and cooperative members was strained, with both sides raising concerns about the lack of commitment from the other party. Only at the end of August did production start, with the yield, however, turning out to be much lower than expected. As a result, feelings of frustration and disappointment emerged among the women, questioning whether mushrooms were the best production option for them, as the idea of "quick and easy money" turned out not to be true. Moreover, no marketing strategies were in place at that stage. The women also considered growing vegetables, as this could at least provide food for their families, contrary to mushrooms, which most of them had never eaten. However, due to a lack of funds to buy seeds, fences, and tools, the women were unable to start producing vegetables during the time of this research. ${ }^{10}$

WFP, on the other hand, experienced the challenge of creating self-reliance and independence among cooperative members, and raised concerns about the ongoing dependency of the participants and a perceived lack of initiative. For example, the cooperative members visited the project site far less often than WFP expected or understood based on the program. According to WFP, the women further were relying too heavily on practical assistance. As a strategy to evaluate

\footnotetext{
${ }^{9}$ In line with our participatory approach, Ana Eisermann collaboratively engaged in production activities and to some extent assisted in the process, while aiming to not dominate or greatly influence it.

${ }^{10}$ Since this research's time period, the cooperative has shifted to producing vegetables and does not engage in mushroom production anymore (Oxfam Canada, n.d.).
}

and reflect on the various programs, WFP held a meeting during the last week of July 2010. In addition to the WFP leadership and program facilitators, participants of the various programs were invited, including the cooperative members. ${ }^{11}$ The meeting revealed the challenges experienced by all stakeholders in developing independent and "empowering" structures, and shed light on the factors compromising the participation of women. ${ }^{12}$

Apart from the challenges experienced with project implementation and participation, it is of central importance in the context researched here that all cooperative members are still living on the premises of one farm owner, on whom they depend for housing, occasional income, and benefits through their employed male partners. Although the cooperative members stated that they are not obliged to explain themselves to the farm owner with regard to their cooperative activities, all of them expressed fear of his potential negative reaction, as he might perceive that the women's engagement in the cooperative could, in the medium or long term, deprive him of an easily accessible and available labor force. Among the reactions they feared were potential eviction from the farm, a family member being retrenched, or not being offered seasonal employment anymore. WFP's position on communication with the farm owners regarding the cooperative program is that the women and the program team should not integrate the farmers into the process of cooperative development. ${ }^{13}$ In WFP's view this would

\footnotetext{
11 Three authors of this paper (Ana Eisermann, Anne Bellows, and Stefanie Lemke) were invited to participate in this meeting while undertaking research in the area. This allowed them access to valuable insights into the debate between the various actors and to reflect on the process. This further demonstrates the openness toward critical reflection from the side of WFP. 12 The difficulties associated with women leaving their homes, for example to participate in this meeting, were explicit. Living in isolated rural settings, they worry that no one will care for or feed their children in their absence, and worse, they fear for the children's potential exposure to abuse. Additionally, the material goods of their household remain unprotected. 13 As was communicated to us by WFP, the organization does in fact collaborate with farm owners with regard to WFP's health and safety program and social security program. Farm owners are interested in participating in these programs as they
} 
serve to perpetuate the paternalistic system and contradict the core principle of empowerment WFP declares as its aim. During one informal meeting with the farm owner, he stated that he has nothing against the cooperative, but he emphasized that he would like to be informed if researchers enter the farm premises, something that had not been done due to the approach of WFP as described above. Another power struggle faced by the cooperative members is within their own households, with many of them experiencing domestic violence and abuse. The women reported conflicts arising about how to use the money obtained from the stipend. One cooperative member was physically abused by her husband and her daughter, who wanted to take the money from her. Another cooperative member was threatened with being evicted by her grandmother. For a third woman, the involvement with WFP is a constant source of conflict, as her family members are afraid that the farmer might take negative actions against them.

\section{Impact of the Program on the Liveliboods of Participating $W$ omen}

The cooperative members receive a monthly stipend of 1,316.69 ZAR (USD174.73), equivalent to the minimum wage of farm workers. The monthly stipend is provided by an international donor and maintained in a bank account held by one cooperative member, who is the only one who has a bank account. Once per month she draws the money when she travels to town and then distributes it to the other cooperative members. WFP was planning to assist the women in establishing a bank account in the name of the cooperative, but this had not materialized by the time of this research. The agreement with WFP is that the stipend is paid to the members until the cooperative is able to generate an income.

Our findings show that participation in organizational development of the cooperative and supportive programming from WFP did make important contributions to enhancing cooperative members' livelihoods. In terms of

gain credibility when engaging with certain incentives required by the government. the capacity to undertake an autonomous agricultural-oriented entrepreneurial project, participation facilitated women's access to land (natural assets), income (financial assets), and agricultural training and technical skills (human assets). Bolstering the specific objective of agricultural cooperatives, WFP introduced more general adult education programs on health, wellbeing, and human rights, focusing on critical topics that are inadequately available in isolated rural communities, such as HIV/AIDS awareness, alcohol abuse and domestic violence, gender equality, and farm workers' rights as well as raising awareness about the availability of related support structures (relating to institutional structures and processes). Also in this case study, these combined livelihood assets have a positive effect on the vulnerability context and on the livelihood outcomes of the women.

It has to be emphasized that the decision of these women to establish a cooperative represents a confrontation with the patriarchal and paternalistic relationships of dependency, both on their male partners and also the farm owner, for all of their lives, having almost no support networks outside of the farm where they live. This is illustrated by the following statement of one cooperative member: "My father laughed when I told him that we will build a cooperative, that we will be our own boss. The only thing he knows is to be a farm worker and to work for the farmer." Overall, the women perceived the following achievements through joining the cooperative: generating an income through the stipend provided by the cooperatives program and thus improving the overall economic and food situation of their households; mobilizing among themselves; gaining organizational and leadership skills; and experiencing greater self-esteem and self-confidence.

\section{Discussion}

\section{Lack of Financial Prospects as Major Challenge for Livelihoods in Smallholder Farming} Most of the women who engaged in the agricultural training program facilitated by GTF do not actually intend to work in agriculture in the long 
term, as illustrated in case study one. Given high unemployment rates and the prospect of an educational certificate, the GTF program offers some advantages, although difficult ones for the participants to survive on financially. Even if the communal land that was obtained by the Grootbos Foundation in the neighboring township could provide an opportunity for these women to engage in smallholder farming in the future, this might not be what they would opt for, for several reasons. First, the prospects of establishing one's own farming business currently are not promising. South African agriculture is still characterized by large-scale farming operations, and there is generally very limited access to infrastructure and a lack of support structures for emerging and smallholder farmers (Greenberg, 2010). Especially in the Eastern Cape, where most of the women come from, drought, poor soil quality, and lack of infrastructure place considerable constraints on people who opt for establishing small-scale farming operations or home gardens (Seti, 2003). Even if certain structures are in place, for example in the form of credits or extension services, people often do not know that they exist or how to access them. Second, the lack of financial prospects in smallholder farming forces the women to seek betterpaid employment. Third, farm labor and farm workers are regarded as having very low social status, due to the history of farming and ongoing poor working and living conditions on many farms. On the other hand, home gardens have been shown to contribute considerably to household nutrition security (Faber et al., 2011). As Aliber \& Hart (2009) and Seti (2003) argue, home gardens have two distinct benefits for the nutrition situation of households. First, the food produced for their own consumption can significantly reduce the households' dependence on purchasing food from the market. Second, this income is fungible and can be spent on other items or on more nutritious foods that the household might not be able to produce. This is in line with our observation that the women's garden plots at the GTF project site provided them with vegetables and thus decreased their purchase of these foods from supermarkets, making considerable contributions to their food supplies and dietary diversity. Further, they were able to sell surplus produce to their neighbors and were thus able to buy other foodstuffs.

Aliber \& Hart (2009) point out, however, that home gardens can only make positive contributions to household food security if certain conditions are fulfilled, such as access to input and output markets (relating to institutional structures and livelihood strategies); extension services (relating to institutional structures); and access to adequate natural resources (relating to livelihood assets). In the case presented here, as long as the women were part of the program at Grootbos Foundation, these structures were largely in place. Once the course was completed, despite some support being offered by the Grootbos Foundation beyond the duration of the course, none of the above mentioned conditions was adequately fulfilled. It is beyond the capacity of the Grootbos Foundation to put all of the required structures in place. Further, with the end of the course the women lost the financial support in the form of a stipend and had to find other employment options that could ensure food supplies for their households.

\section{Power Relations as a Major Challenge for Developing Sustainable Cooperative-based Liveliboods}

In contrast with the women participating in the program of the Grootbos Foundation, women in the agricultural cooperative facilitated by WFP consciously decided to engage in agriculture as a possible future livelihood strategy. The cooperative enabled these women access to various resources, such as income, land, farming implements, and training; this would not have been in reach if they had tried to approach this individually. The ability to follow new livelihood strategies depends on and is affected by different combinations and components of resources that people possess (Scoones, 1998), and these resources, in turn, are widely reported as crucial for women's empowerment (Hashemi, Schuler, \& Riley, 1996; Kabeer, 1999; Malhotra, Schuler, \& Boender, 2002; Rao, 2006). Considering that almost two decades after the end of apartheid a significant part of the South African population is still caught in a structural poverty trap, our findings suggest that the 
cooperatives may leverage transformation and social change that can lead to reducing the poverty status of participating women. Among the positive livelihood outcomes reported are a sense of ownership and a certain degree of control over land, increased confidence and self-esteem, acquisition of new skills, and increased awareness of rights. However, various structural power relations hamper the cooperative's development:

1. high dependency on farm owners who still provide occasional incomes and some social security;

2. power struggles within households and communities; and

3. reliance on the support of WFP.

In the first of these structural power relations, we must recognize that all WFP cooperative members were living on the premises of the farm owner and were either still working for him themselves occasionally or had relatives who were working for him. This situation of financial dependency places women in the new cooperatives and to some extent their families in a highly vulnerable position and delimits their path to greater economic and social autonomy. Clearly, participation in the cooperative alone does not enable participants to break free from the paternalistic structures prevalent on farms that provide services ranging from schools to transportation in isolated rural areas, services that reinforce highly unequal power dynamics between farm owners and farm workers. This patronizing system that stipulates that women's commercial farm employment and access to benefits like housing and water be tied to male family employment magnifies women's particular dependency (cf. Atkinson, 2007; Orton, Barrientos, \& Mcclenaghan, 2001). Our findings illustrate that, because of farm workers' weak position, the women attempt to hide their engagement in the cooperative from farm owners for fear of a backlash, including loss of privileges or even eviction from the farm. This concealment bespeaks the gravity of the unequal power relations and the monumental task of changing them. Secondly, unequal power struggles extend to the patriarchal structure of households. Women are expected to carry out all reproductive work and only work at the farm when labor is needed, creating dire dependency (Orton et al., 2001). Further, exacerbated by the violent inheritance of apartheid and the degrading inequity on many commercial farms, as well as in other contexts, domestic violence is reported at an extraordinarily high rate, compromising the capacity of affected women to pursue their own livelihood strategies (Brown-Luthango, 2006; Shabodien, 2006). Finally, a complex power relationship exists between cooperative members and the organization WFP, which deeply affects members' agency. Research revealed that cooperative members felt pressure to please WFP, as the organization is their best and perhaps only gateway to access resources. WFP, on the other hand, has the challenge of creating self-reliance and independence among the cooperatives. The fact that WFP pays a stipend to cooperative members until they are able to generate an income from their agricultural activities perpetuates their dependency on the organization and might prevent them from investing the time and energy that would be needed to establish their own viable farming business. Kilby (2006) argues that this dynamic of concurrently empowering communities and fostering dependence is common among NGOs and the project groups they support.

\section{Conclusion}

The research presented in this paper reveals the impact of two agricultural programs facilitated by CSOs on the livelihood options of women and on their perceptions regarding participating in these programs. The case studies illustrate that women's access to various resources improved through participation, enhancing their livelihood assets and possibly providing them alternative livelihood strategies in the future. However, several challenges inhibit these programs' abilities to become independent, economically viable, and sustainable:

- the difficulty that participating women face when confronting structurally patronizing and patriarchal power inequities, especially within their own households and communities;

- the ongoing unequal power structures and 
paternalism experienced by farm workers, both women and men, within their working and living environment at the farm;

- the different expectations on the side of program facilitators and participants, and lack of communication between them;

- the dependency of participants on the organization as a limiting factor in achieving autonomy and fostering selfdetermination;

- the lack of access to markets for smallscale trade in locally grown foods; and

- the lack of future prospects in the agricultural sector.

Our observations suggest that significant revision is necessary before these two programs will have a measurable impact on the viability of participants' livelihoods in the long term. We argue, however, that while these programs achieve only part of their desired outcomes with regard to providing sustainable future livelihood strategies for these women, both organizations do make crucial contributions to the lives and livelihoods of these women. It has to be acknowledged that currently no alternatives are in place to the type of programs described here, implying that, without these programs, no such opportunities would open up for the women concerned. We argue further that, given the context of historical injustice and ongoing conditions of rural, racial, gender, and class structural power inequities, the "success" of single programs should be viewed in terms of their ability to leverage, as opposed to shoulder, social change and sustainable livelihoods. The most important contribution might be that participation in these programs breaks the vicious cycle of isolation these women find themselves locked into and stimulates an awareness of possibilities, visions, ownership, and rights among them that can have a medium- or long-term, if not immediate, effect, and that they might be able to apply to various other contexts beyond the agricultural sector in the future. The desire to obtain access to land often is not particularly or exclusively for agricultural production, a fact that is sometimes unexpected for organizations facilitating agricultural programs. Under the present conditions in
South Africa only few households under ideal conditions might be able to strive for and achieve self-sustaining farming operations. For some households, though, smallholder farming or home gardening might serve the purpose of contributing to household food supplies, creating some level of independence from purchasing food. The widely criticized lack of governmental institutions and support structures calls for urgent attention in future revisions of land and agricultural reform programs, in order to address the multiple demands of:

- access to housing and land;

- monitoring and enforcing labor rights and human rights protections, with a specific focus on measures to end violence and discrimination against women; and

- access to health, educational, and transportation services.

With the goal of strengthening civil society and empowering marginalized groups to engage in sustainable livelihood strategies, we hope that our research will contribute both to the work of our partner organizations and to the awareness of South African policy-makers. The findings of the two case studies informed follow-up research that is being pursued in 2012 in cooperation with both organizations, with a specific focus on institutional structures and transforming processes as crucial components of the Sustainable Livelihoods Framework. Applying the SLF enabled us to shed light on underlying conditions and structural inequity among the women observed, confirming that this detailed exploration of location-specific contexts is critical. We emphasize that this framework is not designed to describe rural livelihoods as "farm livelihoods," but that it can be applied to various other rural contexts. Our results only report on two cases and are not representative of South Africa as a whole. It is expected, however, that our findings will be valid for other rural food-insecure regions in the country and, additionally, beyond the South African context, as the present-day realities of marginalized groups in South Africa are not exclusive to the southern African continent or, indeed, to much of the world. 


\section{Acknowledgements}

Stefanie Lemke is funded by a grant from the Ministry for Science, Research and the Arts and the European Social Fund, Baden-Wuerttemberg. Funding for Farideh Yousefi and Ana Eisermann to conduct field research in South Africa was obtained from Foundation fiat panis, Ulm. We would like to thank the Grootbos Foundation, the Women on Farms Project, and all people involved in both programs for their cooperation and for allowing us insights into their achievements and challenges, especially the participating women. A special thanks to Fanie Jansen van Rensburg for valuable feedback on this paper, and to both Fanie and his wife Elsa for great support.

\section{References}

Adult Basic Education and Training [ABET]. (2011). Supporting adult learning in South Africa. Retrieved from http://www.abet.co.za/about.html

Aliber, M., \& Hart, T. G. B. (2009). Should subsistence agriculture be supported as a strategy to address rural food insecurity? Agrekon, 48(4), 434-458.

Altman, M., Hart, T. G. B., \& Jacobs, P. T. (2009). Household food security status in South Africa. Agrekon, 48(4), 345-361.

Amekawa, Y. (2011). Agroecology and sustainable livelihoods: Towards an integrated approach to rural development. Journal of Sustainable Agriculture, 35(2), 118-162. http://dx.doi.org/10.1080/10440046.2011.539124

Atkinson, D. (2007). Going for broke: The fate of farm workers in arid South Africa. Cape Town: Human Sciences Research Council Press.

Bank, L. (2005). On family farms and commodity groups: Rural livelihoods, households and development policy in the Eastern Cape. Social Dynamics, 31(1), 157-181. http://dx.doi.org/10.1080/02533950508628700

Bhaktawar, N., \& Burger, D. (2009). South Africa Yearbook 2009/10. Pretoria, South Africa: GCIS Publications. Retrieved from http://www.gcis.gov.za/content/resourcecentre/sa-info/yearbook/2009-10

Brown-Luthango, M. (2006). Rotten fruits 2: South African farm workers pay a high price for profits. Stellenbosch, South Africa: Women on Farms Project (WFP). Retrieved from http://www.docstoc.com/docs/
19582941/Rotten-Fruits-2-South-African-FarmWorkers-Pay-a-High-Price-for

Chambers, R., \& Conway, G. R. (1992). Sustainable Rural Livelihoods: Practical Concepts for the 21st Century (IDS

Discussion Paper 296). Brighton, U.K.: Institute of Development Studies. Retrieved from http://www.ids.ac.uk/go/idspublication/ sustainable-rural-livelihoods-practical-conceptsfor-the-21st-century

Cousins, B. (2007). Agrarian reform and the "two economies": Transforming South Africa's countryside. In L. Ntsebeza \& R. Hall (Eds.), The land question in South Africa: The challenge of transformation and redistribution (pp. 220-245). Cape Town: Human Sciences Research Council Press.

Creswell, J. W. (2009). Research design: Qualitative, quantitative, and mixed methods approaches (3 $3^{\text {rd }}$ edition). Thousand Oaks, California: Sage.

De Schutter, O. (2011, March 8). Agroecology and the right to food. Report presented by the Special Rapporteur on the Right to Food at the $16^{\text {th }}$ Session of the United Nations Human Rights Council, [A/HRC/16/49]. Retrieved from http://www.srfood.org/images/stories/pdf/ officialreports/20110308 a-hrc-16-49 agroecology en.pdf

Denzin, N. K., \& Lincoln, Y. S. (2008). Collecting and interpreting qualitative materials ( $3^{\text {rd }}$ edition). Thousand Oaks, California: Sage.

Department for International Development [DFID]. (1999). Sustainable Livelihoods Guidance Sheets. London: DFID. Retrieved from http://www.polity.org.za/polity/govdocs/ white papers/landwp.html

Department of Land Affairs. (1997). White paper on South African land policy. Chapter Four: Land Reform Programmes. Pretoria: Department of Land Affairs. Retrieved from http://ww2.ruraldevelopment. gov.za/DLA-Internet/content/document pages/ Legislation and Policies White Papers.jsp

Faber, M., Witten, C., \& Drimie, S. (2011). Communitybased agricultural interventions in the context of food and nutrition security in South Africa. South African Journal of Clinical Nutrition, 24(1), 21-30.

Food and Agriculture Organization of the United Nations [FAO]. (2011). The state of food and agriculture 2010-11: Women in agriculture: Closing the gender gap for development. Retrieved from http://www.fao.org/ docrep/013/i2050e/i2050e.pdf 
FoodFirst Information and Action Network [FIAN] International. (2010). Land grabbing in Kenya and Mozambique: A report on two research missions — and a human rights analysis of land grabbing. Heidelberg: FIAN International. Retrieved from http://www.fian.org/resources/documents/ others/land-grabbing-in-kenya-and-mozambique

Greenberg, S. (2010). Status report on land and agricultural policy in South Africa, 2010 (Research Report No. 40). University of the Western Cape: Institute for Poverty, Land and Agrarian Studies (PLAAS). Retrieved from http://www.plaas.org.za/pubs/ rr/PLAAS RR40 Greenberg.pdf

Grethe, H., Dembélé, A., \& Duman, N. (2011). How to feed the world's growing billions: Understanding FAO world food projections and their implications. Heinrich Böll Foundation (HBF) and World Wildlife Fund Germany (WWF). Retrieved from http://www.boell.de/downloads/2011-05-How-tofeed-the-Worlds-growing-billions.pdf

Grootbos Foundation. (2010). "Grootbos Foundation Mission Statement." Retrieved from http://www.grootbos.com/en/the-grootbosfoundation/mission/

Hashemi, S. M., Schuler, S. R., \& Riley, A. P. (1996). Rural credit programs and women's empowerment in Bangladesh. World Development, 24(4), 635-653. http://dx.doi.org/10.1016/0305-750X(95)00159-A

International Assessment of Agricultural Knowledge, Science and Technology for Development [IAASTD]. (2009). Agriculture at a crossroads: Synthesis report. Washington, D.C.: Island Press. Retrieved from http://www.agassessment.org/reports/ IAASTD/EN/Agriculture $\% 20 \mathrm{at} \% 20 \mathrm{a} \% 20$ Crossro ads_Synthesis $\% 20$ Report $\% 20 \% 28$ English $\% 29$.pdf

International Food Policy Research Institute [IFPRI]. (2005). Women: Still the key to food and nutrition security. Retrieved from http://www.ifpri.org/sites/default/ files/pubs/pubs/ib/ib33.pdf

Kabeer, N. (1999). Resources, agency, achievements: Reflections on the measurement of women's empowerment. Development and Change, 30, 435-464. http://dx.doi.org/10.1111/1467-7660.00125

Kent, G. (2002). A gendered perspective on nutrition rights. $A G E N D A, 51,43-50$.

Kepe, T., Hall, R., \& Cousins, B. (2008). Land. In N. Shepherd, \& S. Robins (Eds.), New South African
Keywords (pp. 143-156). Johannesburg: Jacana \& Athens: Ohio University Press.

Kilby, P. (2006). Accountability for empowerment: Dilemmas facing non-governmental organizations. World Development 34(6), 951-963. http://dx.doi.org/10.1016/j.worlddev.2005.11.009

Labadarios, D., Swart, R., Maunder, E. M. W., Kruger, H. S., Gericke, G. J., Kuzwayo, P. M. N., ... Dannhauser, A. (2008). Executive summary of the National Food Consumption Survey Fortification Baseline (NFCS-FB-I) South Africa, 2005. South African Journal of Clinical Nutrition, 21(3) (Suppl. 2), 247-376.

Lahiff, E. (2008a, 29 August to 4 September). Food crisis makes effective land reform an urgent priority. Mail \& Guardian.

Lahiff, E. (2008b). Land reform in South Africa: A status report 2008 (Research Report No. 38). Cape Town: Programme for Land and Agrarian Studies. Retrieved from http://www.npc.gov.za/MediaLib/ Downloads/Home/Tabs/Diagnostic/Nation Building $2 /$ Land $\% 20$ Reform $\% 20$ in $\% 20$ South $\%$ 20Africa.pdf

Lemke, S. (2010). Food security and right to adequate food in the context of land and agrarian reform in South Africa. In University of Hohenheim, Annual TROZ Report 2008/2009 (pp. 39-40). Retrieved from https://troz.unihohenheim.de/uploads/ media/Report TROZ 2008 2009.pdf

Lemke, S., Bellows, A. C., \& Heumann, N. (2009). Gender and sustainable livelihoods: Case study of South African farm workers. International Journal of Innovation and Sustainable Development, 4(2/3), 195205. http://dx.doi.org/10.1504/IJISD.2009.028073

Loevinsohn, M., \& Gillespie, S. (2003, 12 May). HIV / AIDS, food security and rural livelihoods: Understanding and responding. IFPRI, Washington; ISNAR, The Hague. Retrieved from http://www.ifpri.org/publication/hivaids-foodsecurity-and-rural-livelihoods

Malhotra, A., Schuler, S. R., \& Boender, C. (2002). Measuring women's empowerment as a variable in international development. World Bank Workshop on Poverty and Gender: New Perspectives. Retrieved from http://hdr.undp.org/docs/network/ hdr net/GDI GEM Measuring Womens Empowerment.pdf 
Motsholapheko, M. R., Kgathi, D. L., \& Vanderpost, C. (2011). Rural livelihoods and household adaptation to extreme flooding in the Okavango Delta, Botswana. Physics and Chemistry of the Earth, 36, 984 995. http://dx.doi.org/10.1016/i.pce.2011.08.004

Orton, L., Barrientos, S., \& Mcclenaghan, S. (2001). Paternalism and gender in South African fruit employment: Change and continuity. Women's Studies International Forum, 24 (3/4), 469-478. Retrieved from http://dx.doi.org/10.1016/S02775395(01)00166-2

Oxfam Canada. (no date). Partner profile: Women on Farms Project. Retrieved from http://www.oxfam.ca/whatwe-do/where-we-work/southern-africa/partners/ women-on-farms-project

Privett, S., \& Lutzeyer, H. (2010). Field guide to the flora of Grootbos Nature Reserve and the Walker Bay Region. Gansbaai, South Africa: Grootbos Foundation.

Quisumbing, A. R., Haddad, L., \& Pena, C. (1995). Gender and poverty: New evidence from 10 developing countries (FCND Discussion Paper No. 9). Washington, D.C.: IFPRI.

Quisumbing, A. R., \& Smith, L. C. (2007). Case Study \#4-5, Intrahousehold allocation, gender relations, and food security in developing countries. In P. Pinstrup-Andersen \& F. Cheng (Eds.), Food Policy for Developing Countries: Case Studies (pp. 1-14). New York, Ithaca: Cornell University. Retrieved from http://cip.cornell.edu/dns.gfs/1200428166

Rao, N. (2006). Land rights, gender equality and household food security: Exploring the conceptual links in the case of India. Food Policy, 31, 180-193. http://dx.doi.org/10.1016/j.foodpol.2005.10.006

Rao, N. H., \& Rogers, P. P. (2006). Assessment of agricultural sustainability. Current Science, 91(4), 439-448.

Reddy, V., \& Moletsane, R. (2009). The gendered dimensions of food security in South Africa: A review of the literature. Pretoria: Human Sciences Research Council, Gender and Development Unit.

Scoones, I. (1998). Sustainable rural livelihoods: A framework. for analysis (IDS Working Paper, 72). Institute for Development Studies, Sussex.

Scoones, I. (2009). Livelihoods perspectives and rural development. Journal of Peasant Studies, 36(1), 171-196. http://dx.doi.org/10.1080/03066150902820503
Seti, S. (2003, 27-30 August). Subsistence gardening for food security: A case study of three townships in Grahamstown, Eastern Cape Province. Paper presented at the Eastern Cape Historical Legacies and New Challenges Conference (Working paper 53). Grahamstown, Rhodes University, Institute of Social and Economic Research.

Shabodien, F. (2006). Livelihoods struggles of women farm workers in South Africa. South African Labour Bulletin. Retrieved from http://www.wfp.org.za/ pdf/livelihood struggles of sa women farm workers, 2006.pdf

Shackleton, S., Shackleton, C., \& Cousins, B. (2000). Revaluing the communal lands of Southern Africa: New understandings of rural livelihoods. Natural Resource Perspectives, 62, 1-4. Retrieved from http://www.odi.org.uk/resources/docs/2833.pdf

Statistics South Africa. (2009). Census of commercial agriculture, 2007 (Statistical release P1101). Pretoria: Author. Retrieved from http://www.statssa.gov.za/ publications / Report-11-02-01/Report-11-02012007.pdf

Van Onselen, C. (1996). The seed is mine. The life of Kas Maine, a South African Sharecropper 1894-1985. New York: Hill and Wang.

Von Grebmer, K., Torero, M., Olofinbiyi, T., Fritschel, H., Wiesmann, D., Yohannes, Y.,...von Oppeln, C. (2011). Global Hunger Index 2011: The challenge of hunger: Taming price spikes and excessive food price volatility. Retrieved from http://www.ifpri.org/ sites/default/files/publications/ghi11.pdf

Windfuhr, M., \& Jonsén, J. (2005). Food sovereignty: Towards democracy in localized food systems. The Schumacher Centre for Technology and Development: ITDG Publishing.

Women on Farms Project [WFP]. (2009a). Mission \& vision. Retrieved from http://www.wfp.org.za/ content/XID11-mission vision.html

Women on Farms Project [WFP]. (2009b). Women on Farms Project 2009 annual report. Stellenbosch, South Africa: Author.

World Bank, FAO, \& International Fund for Agriculture Development [IFAD]. (2009). Gender in agriculture sourcebook. Washington, D.C.: The World Bank.

World Bank. (2011). Data: South Africa. Retrieved from http://data.worldbank.org/country/south-africa 